\title{
Obesity alone or with type 2 diabetes is associated with tissue specific alterations in DNA methylation and gene expression of PPARGC1A and IGF2
}

\author{
Miaoxin Chen ${ }^{1,2,3}$, Anne Macpherson ${ }^{2}$, Julie Owens ${ }^{2}$, Gary Wittert ${ }^{1}$, Leonie K. Heilbronn ${ }^{1,2 *}$ \\ Correspondence: leonie.heilbronn@adelaide.edu.au \\ 'Discipline of Medicine, The University of Adelaide, SA. \\ ${ }^{2}$ Robinson Institute, School of Paediatrics and Reproductive Health, The University of Adelaide, SA. \\ ${ }^{3}$ Department of Obstetrics and Gynaecology, The Affiliated Hospital of Guiyang Medical College, Guiyang, China.
}

\begin{abstract}
Background: Epigenetic modifications of key genes have been linked to the development of aging related diseases, such as type 2 diabetes, with increased DNA methylation of the transcriptional co-activator, peroxisome proliferator-activated receptor gamma coactivator 1-alpha (PPARGC1A) in islets and skeletal muscle of patients with type 2 diabetes. Here, we examined DNA methylation and gene expression of PPARGC1A and insulin like growth factor-2 (IGF2) in adipose tissue and skeletal muscle of lean and morbidly obese individuals with or without type 2 diabetes.

Methods: Adipose tissue and skeletal muscle biopsies were collected from 24 lean, obese, and obese patients with type 2 diabetes ( $\mathrm{n}=8$ /group). DNA methylation and gene expression of PPARGC1A and IGF2 were measured using pyrosequencing and quantitative real-time PCR respectively.

Results: DNA methylation and expression of both genes varied in a tissue specific manner $(\mathrm{P}<0.05)$. The highest levels of PPARGC1A methylation were observed in subcutaneous adipose tissue and lowest in muscle $(\mathrm{P} \leq 0.001)$, whereas IGF2 methylation was lowest in subcutaneous adipose tissue as compared with visceral adipose tissue and muscle ( $\mathrm{P} \leq 0.04)$. Expression of PPARGC1A and IGF2 was highest in muscle and lowest in subcutaneous adipose tissue $(\mathrm{P} \leq 0.001)$ and PPARGC1A expression was conversely correlated with DNA methylation in skeletal muscle $(\mathrm{r}=-0.54, \mathrm{P}=0.008)$. Obese patients with type 2 diabetes had higher PPARGC1A methylation in subcutaneous adipose tissue ( $\mathrm{P}=0.01)$ and lower IGF2 DNA methylation in muscle $(\mathrm{P}=0.01)$ as compared with lean individuals. Obese patients with and without type 2 diabetes had reduced expression of both genes in subcutaneous adipose tissue $(\mathrm{P} \leq 0.04)$ as compared to lean individuals.

Conclusions: This study showed tissue specific DNA methylation and gene expression of PPARGC1A and IGF2, which may also be associated with obesity and type 2 diabetes. Further study of the effects of tissue specific DNA methylation on risk of obesity and type 2 diabetes in a larger cohort is now warranted.
\end{abstract}

Keywords: DNA methylation, Gene expression, PPARGC1A, IGF2, Type 2 diabetes, Obesity

\section{Background}

An increasing number of studies suggest that epigenetic modifications in certain genes are associated with subsequent disease susceptibility later in life, both in humans and in animal models [1-4]. For instance, Godfrey et al., reported that lower maternal carbohydrate intake in early pregnancy was associated with increased methylation of retinoid $X$ receptor-a gene in umbilical cord tissue, and higher incidence of childhood adiposity at age 9 years [5]. Supporting this, Relton et al., showed the association between altered DNA methylation patterns in cord blood at birth and later adiposity in childhood, with perturbed gene expression [6]. Individuals conceived during the "Dutch Hunger Winter" famine also had an elevated prevalence of obesity, insulin resistance and cardiovascular disease [1], with reduced DNA methylation of imprinted gene, insulinlike growth factor 2 (IGF2), and increased DNA methylation of non-imprinted genes leptin and interleukin-10 as adults, as compared with their unexposed same-sex siblings $[7,8]$. Whether altered DNA methylation and expression of key genes occurs in peripheral insulin sensitive tissues is a source of current investigation.

Recent studies have demonstrated increased promoter DNA methylation and decreased gene expression of peroxisome proliferator-activated receptor gamma coactivator 1-alpha (PPARGC1A) in pancreatic islets [9], in skeletal muscle from patients with type 2 diabetes [10], and in liver biopsies from individuals with non alcoholic fatty

(C) 2012 Heilbronn et al; licensee Herbert Publications Ltd. This is an open access article distributed under the terms of Creative Commons Attribution License (http://creativecommons.org/licenses/by/3.0),This permits unrestricted use, distribution, and reproduction in any medium, provided the original work is properly cited. 
liver disease [11]. Low birth weight, potentially reflecting in utero deprivation, was also associated with increased PPARGC1A DNA methylation in skeletal muscle in adults at increased risk of diabetes [12]. PPARGC1A is a master regulator of mitochondrial biogenesis and oxidative phosphorylation [13], and is linked to development of insulin resistance and type 2 diabetes [14]. Although reduced PPARGC1A expression in adipose tissue has been reported in insulin resistance [15-17], whether DNA methylation is also altered in this tissue is unknown. Furthermore, whether similar methylation changes in peripheral tissues exist in obese individuals without type 2 diabetes is also unclear.

IGF2 is a key factor in human growth and development and is imprinted through the differentially methylated region (DMR), thus only the paternal allele is expressed. Aberrant imprinting of IGF2 gene is associated with the overgrowth disorder Beckwith-Wiedemann syndrome [18] and the growth restriction disorder Silver-Russell syndrome [19]. Hypomethylation of IGF2 DMRO which is located 5 ' to the main IGF2 promoters in humans [20] leads to bi-allelic expression of IGF2 [21] and is associated with human colorectal cancer, Wilms tumour [21-23], and has also been linked to later development of obesity and insulin resistance in individuals exposed to famine in utero [1]. To date, no studies have examined IGF2 DMR0 methylation and gene expression in adipose tissue and skeletal muscle from patients with obesity and type 2 diabetes.

The present study aimed to determine the tissue specificity of DNA methylation and expression of PPARGC1A and IGF2 and their association with obesity, in the presence and absence of type 2 diabetes, compared with lean individuals, and also, to examine the relationships between DNA methylation patterns and gene expression. The data showed that DNA methylation and gene expression of PPARGC1A and IGF2 occurs in a tissue specific fashion, and that altered DNA methylation and expression of both genes appears to be associated with obesity and type 2 diabetes.

\section{Methods}

\section{Subjects}

The characteristics of 24 subjects are presented in Table 1. Rectus abdominus muscle, subcutaneous adipose tissue and omental adipose tissue biopsies were obtained from eight obese individuals without type 2 diabetes and eight diet controlled obese patients with type 2 diabetes (four females and four males for each group) who were undergoing gastric bypass surgery for the treatment of morbid obesity. Rectus abdominus muscle and abdominal subcutaneous adipose tissue were obtained from four lean males who were undergoing hernia surgery. Vastus lateralis muscle and abdominal subcutaneous adipose tissue were collected from four lean female volunteers [24,25]. All tissues were snap frozen for later analysis. The study was approved by the human research ethics committees of the University of
Adelaide, Calvary Hospital, and Burnside Hospital. Informed consent was obtained from all participants.

\section{DNA and RNA extraction}

Genomic DNA and total RNA were extracted from adipose tissue (120-150 mg) and muscle tissue (10-30mg) using a QIAamp DNA Mini kit (Qiagen, Valencia, CA) and Trizol (Invitrogen, USA) respectively following manufacturer's instructions. The concentration and purity of DNA and RNA were determined by Nanodrop (Thermo Fisher Scientific, California, USA).

\section{Bisulphite modification}

0.4 - $1 \mu \mathrm{g}$ genomic DNA was bisulphite treated to convert unmethylated cytosines to uracil using the MethylEasy ${ }^{\mathrm{TM}}$ Xceed Rapid DNA Bisulphite Modification Kit (Human Genetic Signatures Pty Ltd, NSW, Australia) as per the manufacturer's instructions. All samples were bisulphite treated simultaneously to prevent possible batch effects. There was insufficient subcutaneous adipose tissue sample in one lean and one obese muscle sample for bisulphite conversion.

\section{Nested touchdown PCR}

A nested touchdown PCR strategy was used to amplify bisulphite treated genomic DNA. PCR primers were designed to amplify regions containing specific $\mathrm{CpG}$ sites using Assay Design Software v1.0.6 (Biotage, Uppsala, Sweden).

5 CpG dinucleotides sites in the promoter of the PPARGC1A gene were examined (Supplement figure 1). The outer primers amplify the region on the minus strand of chromosome 4:23892115-23892603 (UCSC BLAT results from Assembly Feb 2009 (GRCh37/hg19)) to yield a 489 bp product, and the inner primers with biotinylated reverse primer and first-round product as template amplify the region minus strand chromosome 4:23892285-23892570 to yield a 286 bp product. The first 4 of these CpG sites were previously measured by Ling et al., in human islets [9] and Brons et al., in human muscle [12]. The $5^{\text {th }} \mathrm{CpG}$ site is identical to that measured by Gemma et al., in umbilical cord blood [26].

Table 1. Clinical characteristics of the subjects

\begin{tabular}{lllll}
\hline & Lean & Obese & $\begin{array}{l}\text { Obese with } \\
\text { diabetes }\end{array}$ & $\begin{array}{l}\text { P } \\
\text { value }\end{array}$ \\
\hline Age (years) & $31 \pm 6^{*}$ & $49 \pm 3$ & $48 \pm 2$ & 0.005 \\
BMI & $22.3 \pm 0.6^{*}$ & $47.6 \pm 1.8$ & $46.3 \pm 1.8$ & $<0.001$ \\
$\begin{array}{l}\text { Fasting Glucose } \\
\text { (mmol/L) }\end{array}$ & $5.2 \pm 0.6$ & $4.9 \pm 0.3$ & $8.5 \pm 1^{*}$ & 0.007 \\
$\begin{array}{l}\text { Total cholesterol } \\
\text { (mmol/L) }\end{array}$ & $5.1 \pm 0.2$ & $5.2 \pm 0.3$ & $5.4 \pm 0.4$ & 0.76 \\
$\begin{array}{l}\text { Triglycerides } \\
\text { (mmol/L) }\end{array}$ & $1.5 \pm 0.2$ & $1.3 \pm 0.1$ & $2.6 \pm 0.8$ & 0.37 \\
\hline
\end{tabular}

Data are presented as mean \pm SEM. *denotes $\mathrm{P}<0.01$ of the asterisked marked group as compared to both other groups. 
5 CpG sites in the IGF2 DMR0 (chr11:2,126,035-2,126,372 in NCBI build 36.1) [27] were also examined (Supplement figure 1). The outer primers amplify the region on Chromosome 11(+ strand): 2169429-2169753 (UCSC BLAT results from Assembly Feb 2009 (GRCh37/hg19)) to yield a 325 bp product. The inner primers with biotinylated reverse primer and firstround product as template amplify the region Chromosome 11:2169452-2169751 to yield a 300 bp product. These sites have been previously quantified by others: all 5 on the minus strand by Steegers-Theunissen et al. [27], and the first 3 on the plus strand by Murrell et al., [23] both in peripheral blood.

All PCR reactions for one tissue were completed simultaneously with the $A B I 7500$ sequence detection system using two MicroAmp ${ }^{\circledast}$ fast 96 -well reaction plates (Applied Biosystems, Foster City, CA). Each PCR reaction also included a no template negative control and unmodified DNA control (Qiagen, Valencia, CA). Only samples with single target size bands without primer dimers were used for pyrosequencing.

\section{Pyrosequencing}

Quantification of cytosine methylation percentage was carried out on a PyroMark MD Pyrosequencing System (Biotage, Uppsala, Sweden) using PyroMark Gold Q96 CDT Reagents 972824 (Qiagen, Valencia, CA). Specific pyrosequencing primers (Supplement table 1) were designed using Biotage Assay Design Software v1.0.6 (Biotage, Uppsala, Sweden). For both genes, two different pyrosequencing assays utilized different forward sequencing primers, with the first to sequence the region containing the first $3 \mathrm{CpG}^{\prime} \mathrm{s}$ of interest, and the second to analyse the 4th and 5th CpG's of interest. Methylation was quantified using Pyro Q-CpG 1.0.9 Software (Biotage, Uppsala, Sweden) which calculated the percentage of methylated cytosines to total cytosines at each CpG site. The mean of five methylated sites was calculated for each sample.

\section{Quantitative real-time PCR}

cDNA was synthesized from $1 \mu \mathrm{g}$ of each RNA sample in 20ul reactions using the QuantiTect reverse transcription kit (Qiagen, Valencia, CA) consistent with the manufacturer's protocol. Standard control samples $(25 \mathrm{ng} / \mu \mathrm{l})$ pooled from each CDNA were diluted to create a standard curve. There was insufficient subcutaneous adipose tissue sample in two obese patients, and one visceral adipose tissue and one muscle sample in the obese group.

Quantitative real-time PCR was performed with the $A B I 7500$ sequence detection system (Applied Biosystems, Foster City, CA) using TaqMan primers and probes for IGF2 (Hs00171254_m1), PPARGC1A (Hs01016719_m1) and Betaactin (Hs99999903-ml) (Applied Biosystems) according to manufacturer's instructions. To calculate the normalized relative expression levels, the individual expression levels of each sample were divided by the expression values of the beta-actin gene, which was not different by groups.

\section{Statistics}

Quantitative data were presented as mean \pm SEM unless indicated. Differences between groups were assessed by one-way ANOVA followed by a Fisher's LSD post hoc test. The effect of obesity on methylation was investigated by linear mixed models, with tissue, individual site methylation, group and sex as between factors and age as a covariate, Bonferroni post hoc test as appropriate. Correlations were calculated using Pearson correlation coefficients for normally distributed values and Spearman correlation coefficients when normality was rejected. Statistical analyses were performed with SPSS 18.0 (SPSS Inc., Chicago, IL, USA). All P values were 2 -sided, and $P \leq 0.05$ was considered significant.

\section{Results \\ Clinical data}

Lean patients were aged between 18-63 years, while obese and obese patients with type 2 diabetes were between 41-56 years of age (Table 1). Obese and obese patients with type 2 diabetes had higher body mass index (BMI) than those who were lean, whereas obese patients with type 2 diabetes had increased fasting plasma glucose compared to lean and obese patients (Table 1). Plasma lipids, including total cholesterol and triglycerides did not vary between groups.

DNA methylation and gene expression of PPARGC1A DNA methylation of PPARGC1A varied significantly between tissues, with the highest DNA methylation in subcutaneous adipose tissue and lowest in muscle (Figure 1A). We also observed the highest expression of PPARGC1A in muscle and the lowest expression in subcutaneous adipose tissue, consistent with these tissue specific patterns of methylation (Figure 1B). Overall, there was also a significant negative relationship between average DNA methylation and gene expression of PPARGC1A gene in muscle (Figure 1C), but not in either visceral or subcutaneous adipose tissue (data not shown). DNA methylation of PPARGC1A in muscle was negatively correlated with age (Figure 1D).

In subcutaneous adipose tissue, obese patients with type 2 diabetes had increased DNA methylation of PPARGC1A compared with lean individuals ( $P=0.01$, Figure 1E), and decreased PPARGC1A expression was also observed in obese patients with or without diabetes as compared to lean individuals ( $P=0.001, P=0.04$, respectively) (Figure 1F). PPARGC1A DNA methylation or gene expression in visceral adipose tissue or muscle tissue did not vary between groups however (data not shown).

\section{DNA methylation and gene expression of IGF2}

As expected for an imprinted gene, DNA methylation of IGF2 was higher than that of PPARGC1A. IGF2 methylation was lowest in subcutaneous adipose tissue as compared to visceral adipose tissue or skeletal muscle (Figure 2A). The expression of IGF2 was lower in visceral adipose tissue than in muscle $(\mathrm{P} \leq 0.001)$ (Figure 2B). IGF2 methylation and 


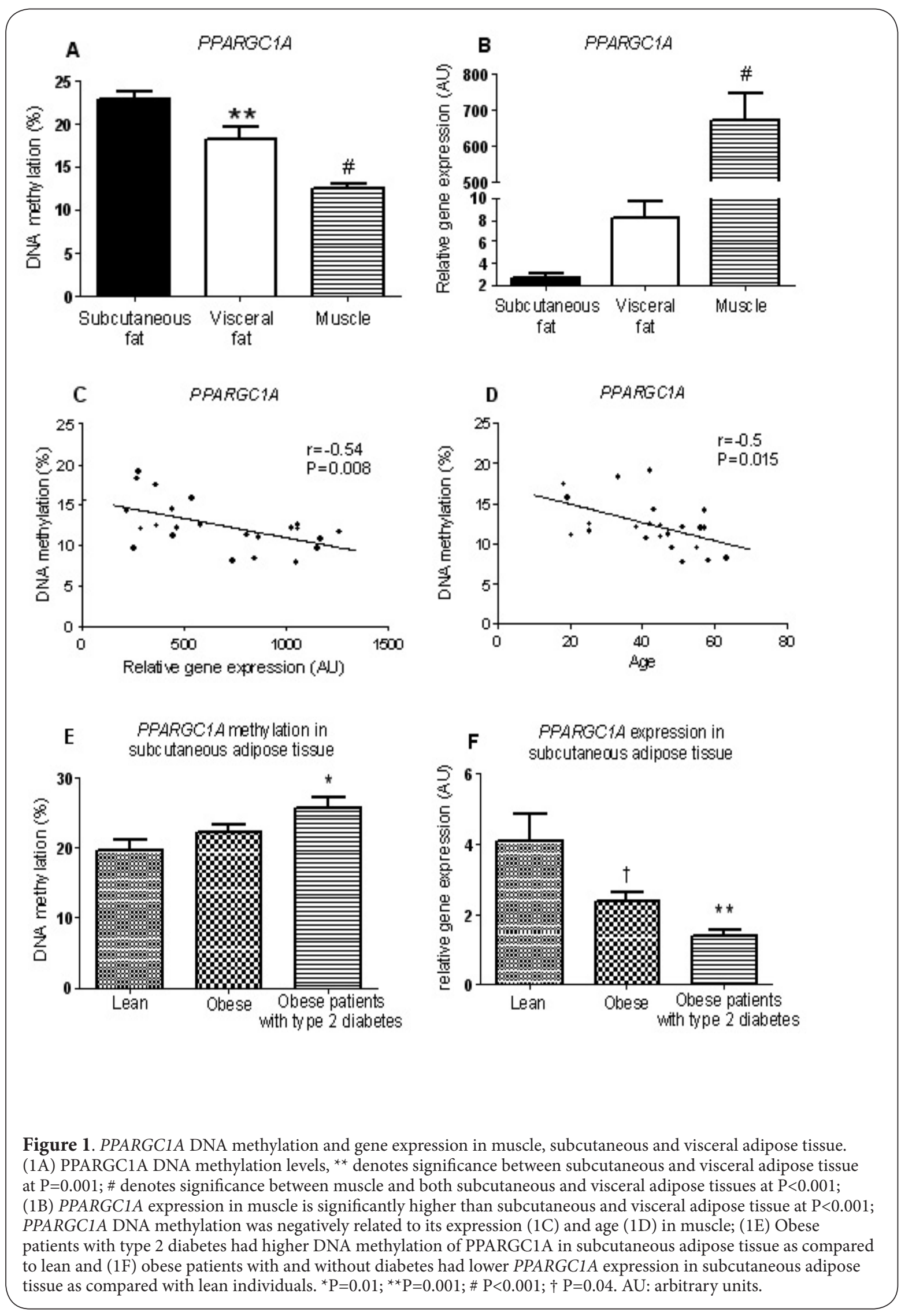


expression in muscle were also significantly correlated with age (Figure 2C and 2D). In skeletal muscle, obese patients with type 2 diabetes had lower DNA methylation than lean individuals $(59 \pm 2 \%$ vs $69 \pm 2 \%, P=0.01)$, but this was not significant between obese and lean individuals $(\mathrm{P}=0.1$ ) (Figure 2E). IGF2 methylation in adipose tissue was not different between groups (data not shown), but IGF2 expression was lower in subcutaneous adipose tissue in obese patients with or without type 2 diabetes as compared with lean individuals (Figure 2F). There was no association between DNA methylation and expression of IGF2 in any tissue examined (data not shown).

\section{Discussion}

Epigenetic modifications in key genes may be important in the development of obesity and type 2 diabetes. In this study, we investigated the expression and DNA methylation of PPARGCIA and IGF2 in subcutaneous and visceral adipose tissues and skeletal muscle from lean, obese and obese individuals with type 2 diabetes. Interestingly, we observed that PPARGC1A and IGF2 gene had tissue specific differences in DNA methylation and expression, and that these may be influenced by obesity type 2 diabetes and aging.

DNA methylation plays a key role in regulating gene expression via the addition of a methyl group to the carbon-5 position of the Cytosine-phosphate-guanine $(\mathrm{CpG})$ dinucleotide sequence in promoter regions, which interferes with the binding of particular transcription factors to DNA [28]. Our results indicate that higher DNA methylation was related to lower gene expression of PPARGC1A in a tissue specific manner. To our knowledge, this is the first study to demonstrate that both subcutaneous and visceral adipose tissue had significant higher DNA methylation of PPARGC1A compared with muscle in humans. Supporting this, our data also show a significant negative correlation between average DNA methylation and gene expression of PPARGC1A across the whole cohort in muscle, although this was not observed in adipose tissue. This is broadly consistent with Barres et al., who showed methylation levels of PPARGC1A promoter were negatively correlated with mRNA expression and mitochondrial DNA in skeletal muscle that was collected from patients with or without type 2 diabetes [10]. Of interest, Ling et al., observed a similar correlation between PPARGC1A promoter methylation and mRNA expression in islets from patients with type 2 diabetes [9]. It is not clear why this association is also not seen in adipose tissue in our study, and may be a reflection of tissue specific factors that separately influence expression.

Previous studies have shown increased promoter DNA methylation of PPARGC1A in skeletal muscle and islets in patients with type 2 diabetes $[9,10]$. Our data also showed this association, but only in subcutaneous adipose tissue. This may be related to different CpG sites being selected for study and the different DNA methylation detection methods employed. We did observe reduced PPARGC1A expression in subcutaneous adipose tissue in obese patients with type 2 diabetes. Reduced PPARGC1A expression has been reported in both visceral and subcutaneous adipose tissues as well as muscle from patients with type 2 diabetes in many studies previously $[10,16,29,30]$. It is not clear why these associations were not observed in visceral adipose tissue, and again may be a reflection of size of cohort or other tissue specific factors that influence expression.

We next examined DNA methylation and expression patterns of IGF2. Firstly and as expected, we detected higher DNA methylation in paternally imprinted IGF2 gene as compared to the non-imprinted PPARGC1A gene $[7,9,12,23,31]$. We also observed visceral adipose tissue and muscle had higher DNA methylation than subcutaneous adipose tissue. However the changes in methylation were not accompanied by inverse changes in expression of IGF2, in that muscle also had higher expression of IGF2. However, this is not necessarily contradictory, as shown by Murrell et al. [23], who reported that DNA methylation of the IGF2 DMRO examined here, may play a role in activation and not suppression of gene expression. This relationship is complex and still requires further investigation, as the expression of the human IGF2 gene is controlled at least by 5 promoters $[20,32,33]$.

To date, few studies have examined associations between DNA methylation and gene expression of IGF2 in obesity and type 2 diabetes. Heijmans et al., showed individuals who were prenatally exposed to the Dutch famine had lower methylation of IGF2 in blood and increased prevalence of obesity, insulin resistance and type 2 diabetes in later life [7,34-36]. In our study, patients with type 2 diabetes also had lower IGF2 DNA methylation in muscle as compared to lean individuals. We also observed lower expression of IGF2 in subcutaneous adipose tissue in obese and obese patients with type 2 diabetes as compared to those who were lean. Together these results suggest that DNA methylation and gene expression of IGF2 may be associated with obesity and type 2 diabetes, but this result needs to be confirmed in a larger, age-matched cohort.

Interestingly, our data showed that aging may be associated with decreased DNA methylation of both genes and increased IGF2 expression in muscle. Supporting this, Heijmans et al., demonstrated IGF2 methylation in blood cells decreased $4 \%$ in 10 years within the age range of $43-70$ years [7]. In contrast, Issa et al., have reported increased methylation of the IGF2 promoter which switched from monoallelic to biallelic methylation during aging in adult human colon, breast and lung tumors [37]. However, Cui et al., reported leukocyte IGF2 methylation was stable to middle age $[38,39]$. A recent longitudinal study also showed DNA methylation levels in five of eight imprinted loci were stable over 2-20 years in blood and buccal cell samples [40]. These results indicate tissue specific difference with aging in humans. Similarly, genome-wide analysis of DNA methylation in rats demonstrated significant 


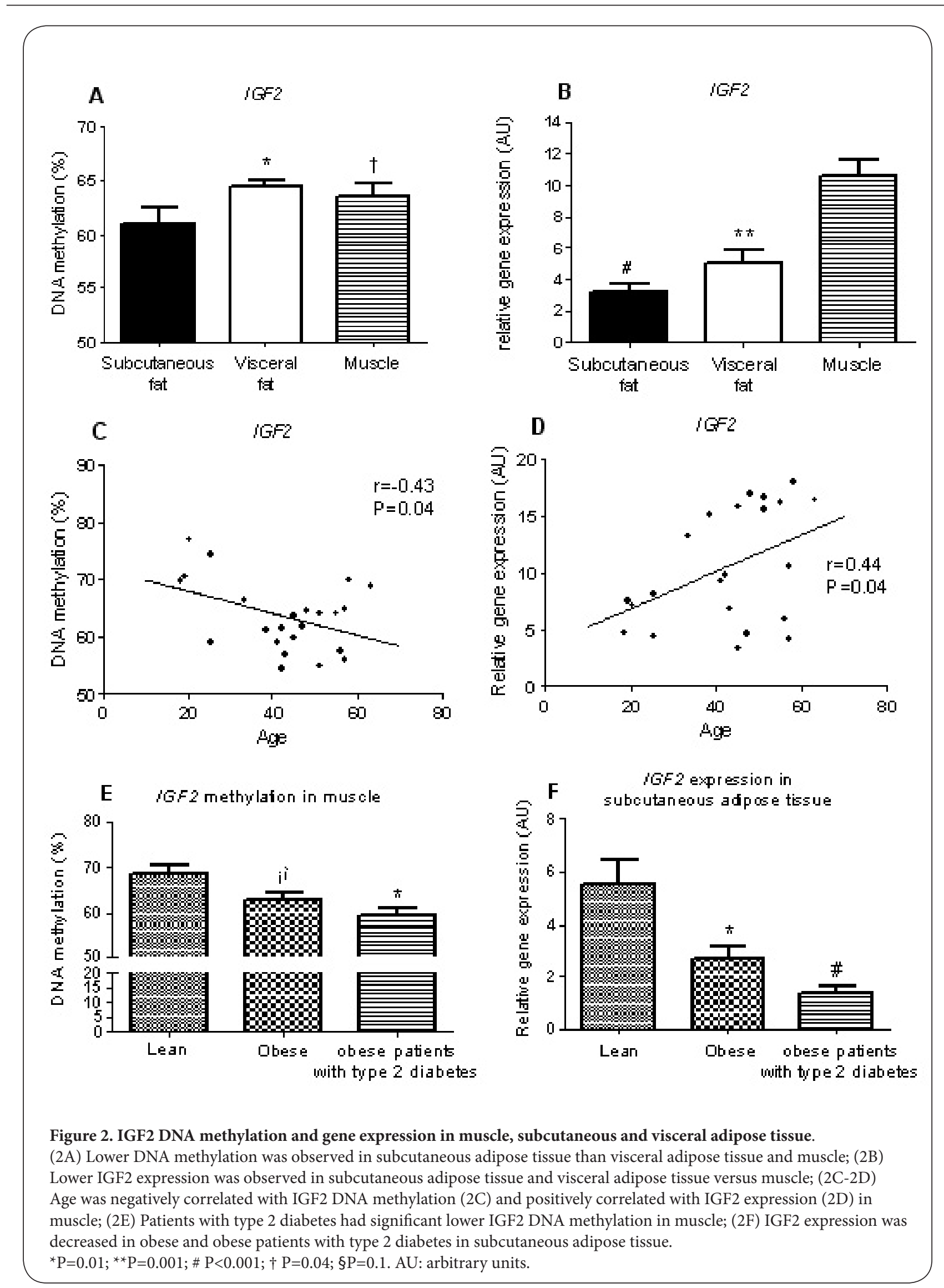


tissue differences and age-related tissue specific changes, including hypomethylation in intra-abdominal tissues and hypermethylation in liver [41]. However, care should be taken when comparing results of these various studies in humans, since different assays, tissues, and the examined loci varied by study [42].

\section{Conclusions}

This study demonstrates tissue specific DNA methylation and gene expression of PPARGCIA and IGF2, which may be related to aging, obesity and type 2 diabetes. The strong negative correlation between DNA methylation and gene expression of PPARGC1A indicates epigenetic regulation may play a key role in expression of this gene, at least in muscle. These outcomes provide the rationale for further study of a larger cohort and emphasize the importance of assessing DNA methylation of these genes at least, in a tissue specific manner in humans.

Additional files

Supplyment figure 1
Supplyment table 1

Competing interests

The authors declare that they have no competing interests.

\section{Authors' contributions}

MC: carried out the epigenetic experiments; participated in the acquisition, analysis and interpretation of the data and drafted the manuscript. AM: designed the pyrosequencing assays, participated in the acquisition of pyrosequencing data, and helped to draft the manuscript.

JO: participated in the design of the study and analysis and interpretation of the data and helped to draft the manuscript. GW: participated in the conception and design of the study and helped to draft the manuscript. LKH: participated in the conception and design of the study, revised the manuscript critically for important intellectual content and gave final approval of the version to be published. All authors read and approved the final manuscript.

\section{Acknowledgements}

The authors acknowledge the Channel 7 Children's

Research Foundation for funding to conduct this study.

Publication history

Editor: Maoqing Dong, Mayo Clinic Arizona, USA.

Received: 14-Aug-2012 Revised: 17-Sep-2012

Accepted: 10-Oct-2012 Published: 30-Oct-2012

\section{References}

1. Roseboom T, de Rooij S, Painter R: The Dutch famine and its longterm consequences for adult health. Early Hum Dev 2006, 82:485491. | Article | PubMed

2. Sinclair KD, Allegrucci $C$, Singh R, Gardner DS, Sebastian S, Bispham J, Thurston A, Huntley JF, Rees WD, Maloney CA, Lea RG, Craigon J, McEvoy TG, Young LE: DNA methylation, insulin resistance, and blood pressure in offspring determined by maternal periconceptional B vitamin and methionine status. Proc Natl Acad Sci U S A 2007, 104:19351-19356. | Article | PubMed Abstract | PubMed Full Text
3. Jirtle RL, Skinner MK: Environmental epigenomics and disease susceptibility. Nat Rev Genet 2007, 8:253-262. | Article | PubMed

4. Tang WY, Ho SM: Epigenetic reprogramming and imprinting in origins of disease. Rev Endocr Metab Disord 2007, 8:173-182. | Article | PubMed Text

5. Godfrey KM, Sheppard A, Gluckman PD, Lillycrop KA, Burdge GC, McLean C, Rodford J, Slater-Jefferies JL, Garratt E, Crozier SR, Emerald BS, Gale CR, Inskip HM, Cooper C, Hanson MA: Epigenetic gene promoter methylation at birth is associated with child's later adiposity. Diabetes 2011, 60:1528-1534. | Article | PubMed Abstract | PubMed Full Text

6. Relton $\mathrm{CL}$, Groom A, St Pourcain B, Sayers AE, Swan DC, Embleton ND, Pearce MS, Ring SM, Northstone K, Tobias JH, Trakalo J, Ness AR, Shaheen SO, Davey Smith G: DNA methylation patterns in cord blood DNA and body size in childhood. PLoS One 2012, 7:e31821. | Article | PubMed Abstract | PubMed Full Text

7. Heijmans BT, Tobi EW, Stein AD, Putter H, Blauw GJ, Susser ES, Slagboom PE, Lumey LH: Persistent epigenetic differences associated with prenatal exposure to famine in humans. Proc Natl Acad Sci U S A 2008, 105:17046-17049. | Article | PubMed Abstract | PubMed Full Text

8. Tobi EW, Lumey LH, Talens RP, Kremer D, Putter H, Stein AD, Slagboom $P E$, Heijmans $B T$ : DNA methylation differences after exposure to prenatal famine are common and timing- and sex-specific. Hum Mol Genet 2009, 18:4046-4053. | Article | PubMed Abstract | PubMed Full Text

9. Ling C, Del Guerra S, Lupi R, Ronn T, Granhall C, Luthman H, Masiello P, Marchetti P, Groop L, Del Prato S: Epigenetic regulation of PPARGC1A in human type 2 diabetic islets and effect on insulin secretion. Diabetologia 2008, 51:615-622. | Article | PubMed Abstract | PubMed Full Text

10. Barres R, Osler ME, Yan J, Rune A, Fritz T, Caidahl K, Krook A, Zierath JR: Non-CpG methylation of the PGC-1alpha promoter through DNMT3B controls mitochondrial density. Cell Metab 2009, 10:189-198. | Article | PubMed

11. Sookoian S, Rosselli MS, Gemma C, Burgueno AL, Fernandez Gianotti $\mathrm{T}$, Castano GO, Pirola CJ: Epigenetic regulation of insulin resistance in nonalcoholic fatty liver disease: impact of liver methylation of the peroxisome proliferator-activated receptor gamma coactivator 1alpha promoter. Hepatology 2010, 52:1992-2000. | Article | PubMed

12. Brons $C$, Jacobsen $S$, Nilsson $E$, Ronn $T$, Jensen $C B$, Storgaard $H$, Poulsen P, Groop L, Ling C, Astrup A, Vaag A: Deoxyribonucleic acid methylation and gene expression of PPARGC1A in human muscle is influenced by high-fat overfeeding in a birth-weight-dependent manner. J Clin Endocrinol Metab 2010, 95:3048-3056. | Article | PubMed

13. Puigserver $\mathrm{P}$, Spiegelman BM: Peroxisome proliferator-activated receptor-gamma coactivator 1 alpha (PGC-1 alpha): transcriptional coactivator and metabolic regulator. Endocr Rev 2003, 24:78-90. | Article | PubMed

14. Soyal S, Krempler F, Oberkofler H, Patsch W: PGC-1alpha: a potent transcriptional cofactor involved in the pathogenesis of type 2 diabetes. Diabetologia 2006, 49:1477-1488. | Article | PubMed

15. Semple RK, Crowley VC, Sewter CP, Laudes M, Christodoulides C, Considine RV, Vidal-Puig A, O'Rahilly S: Expression of the thermogenic nuclear hormone receptor coactivator PGC-1[alpha] is reduced in the adipose tissue of morbidly obese subjects. Int J Obes Relat Metab Disord 2003, 28:176-179. | Article | PubMed

16. Ruschke K, Fishbein L, Dietrich A, Kloting N, Tonjes A, Oberbach A, Fasshauer M, Jenkner J, Schon MR, Stumvoll M, Bluher M, Mantzoros CS: Gene expression of PPARgamma and PGC-1alpha in human omental and subcutaneous adipose tissues is related to insulin 
resistance markers and mediates beneficial effects of physical training. Eur J Endocrinol 2010, 162:515-523. | Article | PubMed Abstract I PubMed Full Text

17. Hammarstedt A, Jansson PA, Wesslau C, Yang X, Smith U: Reduced expression of PGC-1 and insulin-signaling molecules in adipose tissue is associated with insulin resistance. Biochem Biophys Res Commun 2003, 301:578-582. | Article | PubMed

18. Cooper WN, Luharia A, Evans GA, Raza H, Haire AC, Grundy R, Bowdin SC, Riccio A, Sebastio G, Bliek J, Schofield PN, Reik W, Macdonald F, Maher ER: Molecular subtypes and phenotypic expression of Beckwith-Wiedemann syndrome. Eur J Hum Genet 2005, 13:10251032. | Article | PubMed

19. Netchine I, Rossignol S, Dufourg MN, Azzi S, Rousseau A, Perin L, Houang M, Steunou V, Esteva B, Thibaud N, Demay MC, Danton F, Petriczko E, Bertrand AM, Heinrichs C, Carel JC, Loeuille GA, Pinto G, Jacquemont ML, Gicquel C, Cabrol S, Le Bouc Y: 11p15 imprinting center region 1 loss of methylation is a common and specific cause of typical Russell-Silver syndrome: clinical scoring system and epigenetic-phenotypic correlations. J Clin Endocrinol Metab 2007, 92:3148-3154. | Article | PubMed

20. Monk D, Sanches R, Arnaud P, Apostolidou S, Hills FA, Abu-Amero $S$, Murrell A, Friess H, Reik W, Stanier P, Constancia M, Moore GE: Imprinting of IGF2 PO transcript and novel alternatively spliced INSIGF2 isoforms show differences between mouse and human. Hum Mol Genet 2006, 15:1259-1269. | Article | PubMed

21. Cui H, Onyango P, Brandenburg S, Wu Y, Hsieh CL, Feinberg AP: Loss of imprinting in colorectal cancer linked to hypomethylation of $\mathrm{H} 19$ and IGF2. Cancer Res 2002, 62:6442-6446. | Article | PubMed

22. Sullivan MJ, Taniguchi T, Jhee A, Kerr N, Reeve AE: Relaxation of IGF2 imprinting in Wilms tumours associated with specific changes in IGF2 methylation. Oncogene 1999, 18:7527-7534. | Article | PubMed

23. Sullivan MJ, Taniguchi T, Jhee A, Kerr N, Reeve AE: Relaxation of IGF2 imprinting in Wilms tumours associated with specific changes in IGF2 methylation. Oncogene 1999, 18:7527-7534. | Article | PubMed Abstract | PubMed Full Text

24. Samocha-Bonet D, Campbell LV, Viardot A, Freund J, Tam CS, Greenfield JR, Heilbronn LK: A family history of type $\mathbf{2}$ diabetes increases risk factors associated with overfeeding. Diabetologia 2010, 53:1700-1708. | Article | PubMed

25. Heilbronn LK, Gan SK, Turner N, Campbell LV, Chisholm DJ: Markers of mitochondrial biogenesis and metabolism are lower in overweight and obese insulin-resistant subjects. J Clin Endocrinol Metab 2007, 92:1467-1473. | Article | PubMed

26. Gemma C, Sookoian S, Alvarinas J, Garcia SI, Quintana L, Kanevsky D, Gonzalez CD, Pirola CJ: Maternal pregestational BMI is associated with methylation of the PPARGC1A promoter in newborns. Obesity (Silver Spring) 2009, 17:1032-1039. | Article | PubMed

27. Steegers-Theunissen RP, Obermann-Borst SA, Kremer D, Lindemans J, Siebel C, Steegers EA, Slagboom PE, Heijmans BT: Periconceptional maternal folic acid use of $\mathbf{4 0 0}$ microg per day is related to increased methylation of the IGF2 gene in the very young child. PLoS One 2009, 4:e7845. | Article | PubMed Abstract | PubMed Full Text

28. Swales AK, Spears N: Genomic imprinting and reproduction. Reproduction 2005, 130:389-399. | Article | PubMed

29. Patti ME, Butte AJ, Crunkhorn S, Cusi K, Berria R, Kashyap S, Miyazaki Y, Kohane I, Costello M, Saccone R, Landaker EJ, Goldfine AB, Mun E, DeFronzo R, Finlayson J, Kahn CR, Mandarino LJ: Coordinated reduction of genes of oxidative metabolism in humans with insulin resistance and diabetes: Potential role of PGC1 and NRF1. Proc Natl Acad Sci U S A 2003, 100:8466-8471. | Article | PubMed Abstract | PubMed Full Text
30. Mootha VK, Lindgren CM, Eriksson KF, Subramanian A, Sihag S, Lehar J, Puigserver P, Carlsson E, Ridderstrale M, Laurila E, Houstis N, Daly MJ, Patterson N, Mesirov JP, Golub TR, Tamayo P, Spiegelman B, Lander ES, Hirschhorn JN, Altshuler D, Groop LC: PGC-1alpha-responsive genes involved in oxidative phosphorylation are coordinately downregulated in human diabetes. Nat Genet 2003, 34:267-273. | Article | PubMed

31. Tobi EW, Heijmans BT, Kremer D, Putter H, Delemarre-van de Waal HA, Finken MJ, Wit JM, Slagboom PE: DNA methylation of IGF2, GNASAS, INSIGF and LEP and being born small for gestational age. Epigenetics 2011, 6:171-176. | Article | PubMed Abstract | PubMed Full Text

32. Vu TH, Hoffman AR: Promoter-specific imprinting of the human insulin-like growth factor-II gene. Nature 1994, 371. | Article | PubMed

33. van Dijk MA, van Schaik FM, Bootsma HJ, Holthuizen P, Sussenbach JS: Initial characterization of the four promoters of the human insulinlike growth factor II gene. Mol Cell Endocrinol 1991, 81:81-94. | Article | PubMed

34. Roseboom TJ, Painter RC, van Abeelen AF, Veenendaal MV, de Rooij SR: Hungry in the womb: what are the consequences? Lessons from the Dutch famine. Maturitas 2011, 70:141-145. | Article | PubMed

35. de Rooij SR, Painter RC, Roseboom TJ, Phillips DI, Osmond C, Barker DJ, Tanck MW, Michels RP, Bossuyt PM, Bleker OP: Glucose tolerance at age 58 and the decline of glucose tolerance in comparison with age $\mathbf{5 0}$ in people prenatally exposed to the Dutch famine. Diabetologia 2006, 49:637-643. | Article | PubMed

36. Ravelli AC, van der Meulen JH, Michels RP, Osmond C, Barker DJ, Hales $\mathrm{CN}$, Bleker OP: Glucose tolerance in adults after prenatal exposure to famine. Lancet 1998, 351:173-177. | Article | PubMed

37. Issa JP, Vertino PM, Boehm CD, Newsham IF, Baylin SB: Switch from monoallelic to biallelic human IGF2 promoter methylation during aging and carcinogenesis. Proc Natl Acad Sci U S A 1996, 93:1175711762. | Article | PubMed Abstract | PubMed Full Text

38. Cui H, Cruz-Correa M, Giardiello FM, Hutcheon DF, Kafonek DR, Brandenburg S, Wu Y, He X, Powe NR, Feinberg AP: Loss of IGF2 imprinting: a potential marker of colorectal cancer risk. Science 2003, 299:1753-1755. | Article | PubMed

39. Heijmans BT, Kremer D, Tobi EW, Boomsma DI, Slagboom PE: Heritable rather than age-related environmental and stochastic factors dominate variation in DNA methylation of the human IGF2/H19 locus. Hum Mol Genet 2007, 16:547-554. | Article | PubMed

40. Talens RP, Boomsma DI, Tobi EW, Kremer D, Jukema JW, Willemsen G, Putter H, Slagboom PE, Heijmans BT: Variation, patterns, and temporal stability of DNA methylation: considerations for epigenetic epidemiology. FASEB J 2010, 24:3135-3144. | Article | PubMed

41. Thompson RF, Atzmon G, Gheorghe C, Liang HQ, Lowes C, Greally JM, Barzilai N: Tissue-specific dysregulation of DNA methylation in aging Aging Cell 2010, 9:506-518. | Article | PubMed Abstract | PubMed Full Text

42. Martin GM: Epigenetic drift in aging identical twins. Proc Natl Acad Sci U S A 2005, 102:10413-10414. | Article | PubMed Abstract | PubMed Full Text 